\title{
Resignation of director of UK space centre causes storm
}

\section{London}

A political storm has erupted over the British government's refusal to provide any new money for the national space programme and the subsequent resignation of Mr Roy Gibson, director general of the British National Space Centre (BNSC). The future of several of Britain's domestic projects and participation in international ventures is now in doubt.

Last September, at the government's request, BNSC produced a 15 -year plan outlining options for British involvement in space. The plan, which has not been published, required an extra $£ 200$ million on top of the $£ 112$ million that BNSC currently spends. Thatcher's announcement amounted to a rejection of the plan. A compromise sum of $£ 90$ million was also refused. But the final straw for Gibson was the government's refusal to provide $£ 7$ million to tide over preparatory research for two European projects on which Britain is collaborating. Two years ago, the European Space Agency (ESA) agreed to embark on pre-development studies on the Columbus programme of participation in the international space station, the Ariane V rocket launcher and the Hermes space plane.

ESA had intended to hold a ministerial meeting in June to seek approval to start development of the programmes. That meeting was postponed until November, partly because the British government had not decided how much money it would give BNSC. ESA therefore requested extra funding from member states to continue the preparatory studies on Ariane V and Columbus until the November meeting. The British government refused to provide the extra money so Gibson felt obliged to resign.

Within ESA, Britain's influence will be even less after November's meeting. If it is agreed to press ahead with the three bigspending programmes, substantial extra investment will be required from the member states over the next decade. Britain at present contributes 12.6 per cent of ESA's total budget, behind France (29.6 per cent), West Germany (22.5 per cent) and Italy (14.8 per cent). Without extra money, Britain's stake will fall to around 5 per cent if the proposals are approved, and it will be forced to decline to collaborate in one or two of the three big projects, and thus lose out on lucrative commercial contracts.

Shortly after Gibson announced his resignation, he was visited by ESA's director general, Reimar Lüst, and the chairman of the ESA council, Heinrik Grage, ostensibly to discuss ESA's longterm programmes, but they also asked
Gibson to reconsider his decision to resign Afterwards Lüst made it clear that ESA would push on with its space programme regardless of Britain's participation.

Thatcher's suggestion that the private sector should put up more cash for research has infuriated industrialists, who say that many of the space-exploiting technologies are at such an early stage of development that it will be several years before financial returns permit substantial investment in basic research

Gibson's resignation has also put in doubt the future of BNSC as an independent body. It was set up two years ago to coordinate Britain's fragmented space policy and to distribute the space funds of the Department of Trade and Industry (DTI), Ministry of Defence and Department of Education and Science. BNSC assumed that it would eventually be given its own money direct from the Treasury. The decision to establish a national space

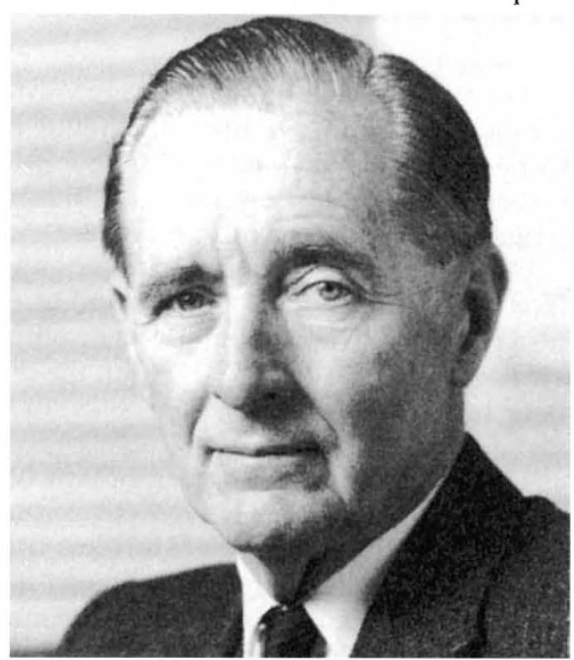

Roy Gibson, ex-director general of BNSC. centre was perceived as a government commitment to Britain's future in space; the appointment of Gibson, an internationally respected figure in space research and ESA's first director general, was seen as further evidence that the British government was taking space seriously.

BNSC's management board will meet at the beginning of September to decide the future of the centre. Gibson will leave at the end of that month, to be replaced by his deputy, Jack Leeming, until he retires at the end of the year.

It is possible that BNSC as a body will be disbanded and coordination of the national space programme transferred to the DTI. Sir Geoffrey Pattie, the former minister of information technology who took the lead in promoting BNSC, said last week that Britain had "abdicated from space".

Simon Hadlington

\section{Cold feet in UK over contract financing}

\section{London}

There are indications that the British government is getting cold feet about its controversial plans for financing universities by contracts, after overwhelming opposition to the proposal. A Department of Education and Science (DES) spokesman confirms that the inflammatory word "contracts" may not even appear in the forthcoming Education Bill.

The concept of contracting, which first appeared in the government's white paper, Meeting the Challenge (see Nature $326,531 \& \mathbf{5 3 2} ; \mathbf{1 9 8 7}$ ), and later in a consultative document, briefly spelled out three options: a single comprehensive contract covering all facets of university activities, including teaching and research; separate contracts for each aspect of a university's activities, including individual courses; or a combination of these two, with a core contract covering teaching and various subsidiary contracts.

Greater accountability was a stated goal of contracting, with the underlying intention to direct education and research into areas required by industry. But educationalists argued that the scheme was unworkable, and a threat to the university system. Opposition to a contract system has been virtually unanimous, with every vice-chancellor in Britain speaking out against it in graduation speeches, annual reports and responses to the consultative document. Even some civil servants are said to consider the proposal clumsy and overbureaucratic.

The DES, the University Grants Committee and the Committee of ViceChancellors and Principals are due to meet for discussions in autumn, but regardless of the outcome there are signs that a contractual system may not be included in the Education Bill. A DES spokesman says details about university funding are not something for primary legislation, and can be sorted out by the new University Funding Council, which will replace the UGC, "without representing a loss of face or a climbdown".

University sources are pleased, albeit somewhat surprised, that the consultative document on the contract system seems to have been just that. Kathy Johnston - The new Education Bill will give business and industry the controlling voice over Britain's 400 further education colleges. The Department of Education has released a report specifying that half the 24 governors on a college governing body will be representatives from employers, and the governors will control college budgets and staff appointments. The government's move continues the trend towards reducing local education authority control over schools and colleges. 